\title{
Hitting a nerve: populist news articles lead to more frequent and more populist reader comments
}

\author{
Blassnig, Sina ; Engesser, Sven ; Ernst, Nicole ; Esser, Frank
}

\begin{abstract}
Although research on effects of populist communication has increased, it is still unclear how populism in news articles affects the readers' manifest behavior, such as whether and how they comment on online news. To address these issues, we conducted a content analysis of online news articles $(\mathrm{N}=332)$ and corresponding reader comments $(\mathrm{N}=2786)$ during election campaigns in France, Switzerland, and the United Kingdom. We find that populist key messages by political and media actors in news articles do not only provoke more reader comments but also prompt citizens to use populist key messages themselves in their comments - regardless of how journalists contextualize these statements.
\end{abstract}

DOI: https://doi.org/10.1080/10584609.2019.1637980

Posted at the Zurich Open Repository and Archive, University of Zurich

ZORA URL: https://doi.org/10.5167/uzh-173299

Journal Article

Accepted Version

Originally published at:

Blassnig, Sina; Engesser, Sven; Ernst, Nicole; Esser, Frank (2019). Hitting a nerve: populist news articles lead to more frequent and more populist reader comments. Political Communication, 36(4):629-651.

DOI: https://doi.org/10.1080/10584609.2019.1637980 


\title{
Hitting a Nerve: Populist News Articles Lead to More Frequent and More Populist Reader Comments
}

\author{
Sina Blassnig, Sven Engesser, Nicole Ernst, and Frank Esser
}

\begin{abstract}
Although research on effects of populist communication has increased, it is still unclear how populism in news articles affects the readers' manifest behavior, such as whether and how they comment on online news. To address these issues, we conducted a content analysis of online news articles $(\mathrm{N}=332)$ and corresponding reader comments ( $N=2786$ ) during election campaigns in France, Switzerland, and the United Kingdom. We find that populist key messages by political and media actors in news articles do not only provoke more reader comments but also prompt citizens to use populist key messages themselves in their comments - regardless of how journalists contextualize these statements.
\end{abstract}

Keywords: populism, populist communication, online news, reader comments, election campaigns

It is a widely established hypothesis that populism in the media affects media users (Aalberg, Esser, Reinemann, Strömbäck, \& de Vreese, 2017; de Vreese, Esser, Aalberg, Reinemann, \& Stanyer, 2018). However, most empirical studies have focused on attitudinal effects (Bos, van der Brug, \& de Vreese, 2011, 2013; Hameleers, Bos, \& Vreese, 2017, 2018; Hameleers \& Schmuck, 2017; Matthes \& Schmuck, 2017). It remains an open question if populism in the media may also induce populist behavior, such as the expression of populist ideology in public discourse. We know that the use of uncivil media may lead to an increased use of incivility in political expressions (Gervais, 2014), but we do not know if this finding from incivility research can also be applied to the area of populist communication.

Previous research has shown that populist communication can influence populist attitudes (e.g., Hameleers \& Schmuck, 2017; Müller et al., 2017), attitudes towards migrants (e.g., Matthes \& Schmuck, 2017; Wirz et al., 2018), emotions (Wirz, 2018b; Wirz et al., 2018), the perception of political actors (e.g., Bos et al., 2013), voting behavior (e.g., Sheets, 
Bos, \& Boomgaarden, 2016), and political engagement (e.g., Hameleers, Bos, Fawzi et al., 2018). These studies have mostly relied on experimental settings, while empirical studies under real-life conditions are scarce (rare exceptions: Bos et al., 2013; Müller et al., 2017; Wirz et al., 2018). Most of these experiments measured only planned and not manifest behavior. However, because planned behavior may be influenced by social desirability, past behavior, and anticipated emotions, it is often only an inaccurate approach to actual behavior (Armitage \& Conner, 2001; Perugini \& Bagozzi, 2001). More recently, research has also started to analyze effects of populist communication on user reactions on social media, relying on content analysis instead of surveys or experiments (Blassnig, Ernst, Engesser, \& Esser, forthcoming; Bobba, 2018). This approach using digital trace data (Howison, Wiggins, \& Crowston, 2011) has the advantage of a higher external validity. This is specifically relevant with regard to populist communication; in an artificial experimental situation, citizens may be more hesitant to express populist messages due to social desirability.

To narrow this substantive and methodological gap in the research, we pursue the question of how populist online news influences the number and content of reader comments. Reader comments are a particularly worthwhile object of investigation because of their dual nature. They can be regarded not only as an expression of communication behavior but may also influence other readers (e.g., Lee, 2012; e.g., Lee \& Jang, 2010; Zerback \& Fawzi, 2016). Furthermore, by focusing on online news, we can investigate populist statements by three key groups of actors - politicians, the media, and citizens (de Vreese et al., 2018) - and their interactions within the same platform.

We follow a communication-centered approach (de Vreese et al., 2018; Stanyer, Salgado, \& Strömbäck, 2017) and conceptualize populism as a 'thin' ideology (Hawkins, Carlin, Littvay, \& Rovira Kaltwasser, 2018; Mudde, 2004) that political actors, journalists, and citizens can express via specific populist key messages (Blassnig, Ernst, Büchel, 
Engesser, \& Esser, 2019; Ernst, Engesser, Büchel, Blassnig, \& Esser, 2017; Müller et al., 2017; Wettstein, Esser, Schulz, Wirz, \& Wirth, 2018; Wirth et al., 2016; Wirz et al., 2018).

We conducted a content analysis of news articles and corresponding reader comments during election campaigns in France, Switzerland, and the United Kingdom. We find that populist key messages by political and media actors in news articles do not only provoke more reader comments but also prompt citizens to use populist key messages themselves in their comments - regardless of how journalists contextualize these statements.

\section{Populist Online Communication}

Connecting approaches in political science and communication science, we conceive of populism as a 'thin' ideology (Mudde, 2004) or a "set of ideas" (Hawkins \& Kaltwasser, 2018; Taggart, 2000) that can manifest discursively in the communication of political actors, media actors, or citizens (de Vreese et al., 2018).

At the core of populist ideology lies the Manichean juxtaposition of the pure, good people to a corrupt, detached elite, as well as the demand that politics should be an expression of the unrestrained popular will (Mudde, 2004). Furthermore, populist ideology conceives of 'the people' as a monolithic entity that can have a common will, common desires and common interests. Consequentially, specific social groups who do not share the people's "good" characteristics, values, or opinions are perceived as out-groups or as "dangerous 'others"” (Albertazzi \& McDonnell, 2008, p. 3). While 'the elite' is subject to a vertical differentiation from 'the people', 'the others' are the target of a horizontal exclusion (Abts \& Rummens, 2007). Following this conceptualization, populist ideology consists of four dimensions: people-centrism, anti-elitism, popular sovereignty, and the exclusion of others.

With regard to the fourth dimension, it is disputed whether the exclusion of others is a core element of populist ideology or specific of right-wing populism (see e.g., Engesser, Fawzi, \& Larsson, 2017). Following de Vreese et al. (2018), we argue that the construction of 
specific out-groups is inherent in populism's monolithic conception of the people but that not all types of populism necessarily exclude a specific social group.

This populist ideology can be communicated by various actors by means of populist key messages. Consequentially, we do not argue that there are populist actors per se but that populism is a matter of degree and that anyone can become a 'populist' by communicating populist key messages (de Vreese et al., 2018). From a political communication perspective, three key actors are of particular interest as communicators of populist key messages: 1) political actors, 2) the media, and 3) citizens (de Vreese et al., 2018).

Political actors have been featured most prominently in research on populism. Previous research shows that, on the one hand, populist communication is most often used by parties at both extremes of the political spectrum, opposition or challenger parties (Ernst et al., 2017). On the other hand, politicians of mainstream or moderate parties also rely on populist communication to some extent (Blassnig, Ernst, Büchel, \& Engesser, 2018). Although new media allow politicians to circumvent traditional gatekeepers (Ernst et al., 2017), political actors are still highly reliant on journalistic media to gain a broad publicity for their messages. In turn, due to a high news value and compatibility with media logic, populist messages specifically meet the selection criteria of news media (Mazzoleni, 2008).

This leads to the second actor group of populist communication: the media. Esser, Stępińska, and Hopmann (2017) distinguish between populism through the media and populism by the media. In brief, from the perspective of populism by the media, the communicators of populist messages are the media (i.e., journalists) themselves, whereas populism through the media relates to populist messages by political actors that are disseminated through the media. Thus, the media can act as originators of populist key messages as well as a platform for populist communication by other actors, mostly by 
political actors. Furthermore, journalists can, of course, also criticize or challenge populist messages by political actors (Wettstein et al., 2018).

Such mediated populist messages by political or media actors are then received by citizens - the third actor group (de Vreese et al., 2018). On the one hand, this raises questions about the effects of populist communication on citizens (see e.g. Müller et al., 2017). On the other hand, citizens can become populist actors themselves. Especially online media allow the audience to engage easily with populist content by liking, sharing, or commenting. Thereby, citizens themselves can voice populist ideas in reaction to news coverage, which (Esser et al., 2017) refer to as "populist citizen journalism."

The characteristics of online news media, such as the attention economy of the Internet, an increasingly commercialized media logic, and a more direct connection to the people, may foster populist communication by political actors, the media, and citizens (Blassnig et al., 2019). Online, these three actor groups can directly interact, and their communication is intertwined within the same platform. Populist key messages by political actors are cited and interpreted by the news media, and resonate with citizens as readers who like, share, or comment on such messages.

\section{Online Reader Comments in the Public Sphere}

The ability to directly comment on online news articles allows readers to actively engage with the news. In the literature, reader comments are associated both with positive as well as with negative developments for the online public sphere.

From the perspective of the media, high numbers of reader comments generate website traffic and contribute to high click rates (Anderson, 2011). Thus, reader comments can serve as popularity cues, indicating the attention received or the relevance of an article (Bene, 2017; Porten-Cheé, Haßler, Jost, Eilders, \& Maurer, 2018). They may raise news consumer engagement and loyalty and are, therefore, often desirable from a commercial point 
of view (e.g., Vujnovic, 2011). Comments may also allow a more reciprocal exchange between journalists and their readers (Lewis, Holton, \& Coddington, 2013). However, problematic aspects, such as incivility or hate speech, present challenges for journalists and media organizations (e.g., Coe, Kenski, \& Rains, 2014; Stroud, Scacco, Muddiman, \& Curry, 2015).

For citizens, reader comments provide a public space to interact with news content, voice their opinions, learn about other opinions, and debate with others (Ruiz et al., 2011; Springer, Engelmann, \& Pfaffinger, 2015; Stroud et al., 2015; Ziegele, Quiring, Esau, \& Friess, 2018). Reader comments can contribute to a deliberative online public sphere, given that they adhere to specific standards, such as civility, reciprocity, or openness (Dahlberg, 2011). From a liberal individualist perspective, comments serve the uninhibited selfexpression, possibly at the expense of deliberative standards (Freelon, 2015).

From a communitarian perspective, reader comments may serve as a means to collaborate with like-minded others to advance specific ideological goals while disengaging from outsiders (Freelon, 2015). Additionally, comment sections can constitute counter publics, where citizens express opinions that challenge the mainstream media or the perceived dominant public sphere (Toepfl \& Piwoni, 2015). Thus, from a participatory point of view, encouraging citizens to write comments may raise inclusion and opinion diversity, and promote a broader participation in the online public sphere (Ruiz et al., 2011; Toepfl \& Piwoni, 2015; Weber, 2014; Ziegele et al., 2018).

However, user comments are often also viewed as an aspect of several problematic developments in the online public sphere. Incivility and its effects on the deliberative quality of online discussions have been a central concern in previous research (Coe et al., 2014; Gervais, 2014; Ziegele et al., 2018). In contrast to counter publics, it has also been argued that comments may act as "echo chambers" that reinforce the opinion perceived as dominant 
within a certain media outlet or social group (Jamieson \& Cappella, 2010; Walter, Brüggemann, \& Engesser, 2016). Several authors have warned that in a high-choice media environment, this may lead to increasingly polarized or fragmented audiences (Blumler \& Kavanagh, 1999; Sunstein, 2002; Van Aelst et al., 2017). However, a growing number of recent empirical studies have put this into question (e.g., Fletcher \& Nielsen, 2017; Webster \& Ksiazek, 2012).

Several of these aspects may render reader comments particularly prone to populist communication (Blassnig et al., 2019). Perceiving comment sections as communitarian spaces, counter publics, or echo chambers involves the construction of in- and out-groups, the conception of a people with a closed, collective identity, and the use of "us" vs. "them" rhetoric, which are all central characteristics of populist communication (Abts \& Rummens, 2007; de Vreese et al., 2018; Mudde, 2004). The role of comments as liberal individualist self-expression brings to mind the populists' self-proclaimed defense of freedom of speech and zeal against the 'political correctness' of the elites (Moffitt, 2016; Mudde, 2004). Additionally, reader comments are subject to less editorial control, norms, and gatekeeping processes that may filter out or attenuate populist communication in editorial content (Krämer, 2017).

\section{The Influence of Populism in News Articles on Reader Comments}

Our focus lies on the connection between populism in online news articles and the corresponding reader comments. On the one hand, as popularity cues, comments may contribute to higher click-rates and circulation of online news articles that contain populism, thereby providing a higher reach for these populist messages. On the other hand, the reader comments themselves may include and propagate populist statements.

In general, the characteristics of online news articles influence the level of participation in comment sections. Based largely on news value theory, previous research 
suggests that controversial issues, political or social conflicts, and negative or provocative messages (Tenenboim \& Cohen, 2014; Ziegele et al., 2018; Ziegele, Breiner, \& Quiring, 2014), certain news factors (Weber, 2014), or a generally high news value (Ziegele et al., 2018) can increase the number of commenters that respond to an article.

Populist communication has been described as highly compatible with media logic and attributed with a high news value (Mazzoleni, 2008). Populist messages often co-occur with a negative, emotionalized, or dramatized communication style (Ernst, Blassnig, Engesser, Büchel, \& Esser, 2019). Therefore, it can be assumed that the occurrence of populist key messages may have a positive impact on the amount of comments an article receives. This is also supported by initial empirical evidence that populist content (Blassnig et al., forthcoming; Bobba, 2018) and related stylistic devices (Bene, 2017; Heiss, Schmuck, \& Matthes, 2018) stimulate audience response on social media.

Based on the literature on effects of populist communication, these findings could be explained by different persuasion processes. From the perspective of social identity theory (Tajfel \& Turner, 2004), populist communication invokes specific in-group and out-group identities (Hameleers et al., 2017; Hawkins \& Kaltwasser, 2018, p. 9; Schulz, Wirth, \& Müller, 2018): the pure people as threatened in-group against the corrupt elites and dangerous 'others' as out-groups (Hameleers, Bos, \& Vreese, 2018). This perception of in-group deprivation and out-group threat can mobilize people and trigger collective action (Hameleers, Bos, Fawzi et al., 2018; Simon \& Klandermans, 2001; van Zomeren, Postmes, \& Spears, 2008). Furthermore, populist communication could provoke reactions via emotional persuasion processes (Hawkins \& Kaltwasser, 2018; Wirz, 2018b). Populist messages can be explicitly emotional or include characteristics that make them more likely to elicit emotional responses through appraisal processes (Wirz, 2018b). Both positive and negative emotions mostly anger, fear, hope, and pride - have been associated with populism, whereas especially 
anger and hope have been shown to increase the persuasiveness of populist demands (Wirz, 2018b) and may also increase the willingness to respond to such messages.

This leads to the first hypothesis:

H1 Articles that contain populist key messages receive higher numbers of reader comments.

a. Articles that contain populist key messages by political speakers receive higher numbers of reader comments.

b. Articles that contain populist key messages by media speakers receive higher numbers of reader comments.

Journalistic content does not only have an impact on how many people comment on news articles but also on the content of online discussions (Gervais, 2014; Walter et al., 2016; Ziegele et al., 2018). Toepfl and Piwoni (2017) found that the emphasis structure of news articles predicts the emphasis frames used in attendant reader comments. Gervais (2014) shows that the use of media with higher levels of incivility leads to an increased use of incivility in the political expression of citizens. Walter et al. (2016), focusing on the topic of climate change, suggest that comment sections function as echo chambers.

Similarly, we believe that populism in news articles and populism in reader comments are related to each other. Krämer (2014) argues that populist communication activates a type of "populism schema," i.e., cognitive schemata that are related to the core dimensions of populist ideology. Accordingly, we may assume that populist media content has priming effects, making latent populist attitudes of recipients more salient in the short or long term (Krämer, 2014). Generally, (media) priming refers to effects of mediated content on people's subsequent judgements or behaviors (Roskos-Ewoldsen, Roskos-Ewoldsen, \& Carpentier, 2002). More specifically, priming effects increase the (short-term) accessibility of certain concepts in memory, which may then have an increased likelihood of being used in 
subsequent evaluations (Roskos-Ewoldsen et al., 2002). Thus, from the perspective of priming, populist communication activates preexisting populist ideas or attitudes in the memory of recipients, which means that the user is more likely to use them in judgements or evaluations in response to a message. In newspaper articles, populism is usually not presented as a thoroughly elaborated ideology, but as a collection of fragments. In this context, schema theory assumes that it is often sufficient to highlight one element of a cognitive cluster to coactivate other elements of the cognitive cluster (Bartlett \& Burt, 1933; Brewer \& Nakamura, 1984; Iran-Nejad, 1984). Thus, a news article that contains one dimension of populist communication may also make other dimensions more salient and, consequently, activate populist attitudes in total (Müller et al., 2017).

Populist ideas may serve as an interpretative framework for various events and can therefore also be understood as a frame (Aslanidis, 2015; Hawkins \& Kaltwasser, 2018). In addition to the priming approach, the cognitive effects of populist communication can also be examined with a framing approach. Previous studies have for example argued that populist communication affects recipients' attitudes via value framing (Wirz, 2018a) or blame attributions (Hameleers et al., 2017).

Findings by Müller et al. (2017) suggest that exposure to populist messages in the news leads to more populist attitudes, but only for those citizens who already agreed with populist ideas beforehand, overall fostering polarization. Similarly, Hameleers and Schmuck (2017) found in an experiment that populist messages communicated via social media increase populist attitudes only if recipients supported the source of the message. According to Wirz et al. (2018), anti-immigrant messages in the media lead to more negative cognitions toward immigrants, while populist content in general leads to more negative emotions.

Therefore, we formulate the second hypothesis, as follows: 
$\mathrm{H} 2$ Comments are more likely to be populist if they respond to an article containing populist key messages.

a. Comments are more likely to be populist if they respond to an article containing populist key messages by political speakers.

b. Comments are more likely to be populist if they respond to an article containing populist key messages by media speakers.

The question arises whether this effect depends on how the media contextualize populist statements. The media may convey populist key messages by politicians in different ways. In addition to being originators of populist messages and gatekeepers for populist statements by political actors, the media may also interpret populist actors or ideas in their coverage and evaluate them positively or negatively (Esser et al., 2017; Wettstein et al., 2018). The media may neutrally disseminate populist key messages, attenuate or criticize them, or support, legitimize or reinforce them (Blassnig et al., 2019), and this may also influence the effect that they have on readers and their comments. Thus, how journalists transmit and interpret populist key messages may influence how citizens react to such articles in reader comments. Therefore, we formulate an additional open research question, as follows:

RQ1 Does the contextualization of populist key messages in news articles have an influence on the use of populist communication in reader comments?

\section{Method}

We conducted a quantitative content analysis of reader comments and the respective news articles during election campaigns in France (2017), Switzerland (2015), and the United Kingdom (2015). Additionally, we focused on online news coverage of the issue of immigration. 


\section{Sample}

In the selection of the countries, we followed a most different systems within most similar systems design. On the one hand, we selected countries that have similar political, economic, and cultural settings within Western Europe. In addition, in all three countries (right-wing), populist parties were rather successful in the last European or national elections and have similar positions with regard to migration policy and EU integration. On the other hand, France, Switzerland, and the United Kingdom differ distinctly with regard to their types of political systems and media systems (Hallin \& Mancini, 2004; Lijphart, 1999). This allows to investigate the relation between populism in articles and reader comments in varying contexts and enables a higher generalizability of our findings within Western Europe (Esser \& Vliegenthart, 2017).

The investigation period covers the six weeks before the most recent, regular national elections in the three countries. For the United Kingdom, we included the national parliamentary elections on May 7, 2015, for Switzerland, the national parliamentary elections on October 18, 2015, and for France, the presidential elections, with the first round occurring on April 23 and the second round on May 7, 2017. Election campaigns offer themselves as an inquiry period to investigate populist communication and reader comments, as they provide a pointed view of a country's political communication culture (Esser \& Strömbäck, 2012) as well as a particularly contested environment in which populism is most likely to manifest itself (Plasser \& Ulram, 2003). As populism is a rare and fragmented phenomenon in the overall news media coverage, the identification of a political issue that is affine to populism and has the potential of higher levels of populist messages was crucial (Ernst, Esser, Blassnig, \& Engesser, 2018). We focused on the populism affine topic of immigration because this topic is a polarized and conflict-laden issue and is particularly prone to right-wing populist rhetoric (Taggart, 2017). Recent comparative studies conducting qualitative interviews have 
found that journalists and politicians across several European countries see the topic of immigration as one of the most important drivers of populism (Salgado et al., 2019; Stanyer et al., 2019). Additionally, content analyses across European countries found that immigration was the most commented on topic in print news and among the topics that showed the highest share of populist messages (Ernst et al., 2018; Esser et al., 2019). Consequently, immigration is a highly important topic that is similarly relevant across the three investigated countries. It poses a particular challenge to responsible media coverage and may be specifically vulnerable to populist reader comments (Sheets et al., 2016).

We incorporate five online news outlets per country, comprising print-parent, TVparent, and pure online outlets (see Table 1). For each country, we included the online outlets of two leading upmarket daily newspapers, the dominant mass-market daily paper, one TVparent outlet, and the most important pure online outlet in each country.

Table 1: Online news outlets

\begin{tabular}{llccc}
\hline & & \multicolumn{3}{c}{ Country } \\
\cline { 3 - 5 } & & France & Switzerland & UK \\
\hline \multirow{3}{*}{ Print-parent } & Lefigaro.fr & Nzz.ch & Telegraph.co.uk \\
& Up-market & Lemonde.fr & Tagesanzeiger.ch & Theguardian.com \\
& Mass-market & Leparisien.fr & Blick.ch & dailymail.co.uk \\
\hline \multirow{2}{*}{ TV-parent } & Public & Info.france2.fr & Srf.ch & Bbc.co.uk \\
\hline \multirow{2}{*}{ Pure online } & tempsreel.nouvelobs.co & Watson.ch & \multirow{2}{*}{ Huffingtonpost.co.uk } \\
\hline
\end{tabular}

To sample the relevant online news material, we followed a user-based sampling approach, placing the user perspective at the center and incorporating search strategies that are common in the everyday practice of the average Internet user. In this way, the sample is less representative of the overall population of news articles but more representative of the population that the users are actually confronted with. We relied on Google to search the specific news websites, using the same web browser (Google Chrome) in the "incognito" browsing mode for all searches and disabling the search history to ensure comparability and 
replicability. To ensure that the sampled articles related to the topic of immigration as well as to domestic politics, we used an immigration search string that additionally contained commonly used abbreviations or labels for four selected parties per country. ${ }^{1}$

For each news outlet, we then googled the search string translated into the respective language, restricted the search to the respective news website (site:website.com) and the time frame to the selected six weeks, and downloaded the first 30 listed news items (the first three pages). This yielded $n=433$ news article of which $n=332$ received at least one comment. For these articles, we sampled the first ten reader comments - , i.e., the first ten comments, chronologically, that were posted in direct response to the article. ${ }^{2}$ The final sample comprises 332 articles and 2786 reader comments.

\section{Operationalization and Coding Procedure}

Populist key messages. We regard populist communication as a formative measure (Diamantopoulos, Riefler, \& Roth, 2008) based on the four dimensions and corresponding twelve populist key messages (see Table 2). The key messages were operationalized as dummy variables based on Cranmer (2011), Jagers and Walgrave (2007), and Wirth et al. (2016). For each category, we coded at the story level whether a given populist key message was present in an article or comment.

Speaker. For each populist key message, we coded whether the speaker was a political actor, a media actor, or a citizen. Populist statements by other actors were not incorporated in the analysis. A political speaker was a political actor who was quoted in the story either directly or indirectly. If the journalist herself made a populist statement, the speaker was coded as a media actor. For reader comments, the speaker was coded as citizen (except if the commenter was evidently a political or media actor). 
Table 2: Operationalization of populist communication

\begin{tabular}{|c|c|c|}
\hline Dimension & Populist key message & Description \\
\hline \multirow{4}{*}{ People-Centrism } & Approaching the people & $\begin{array}{l}\text { The speaker describes himself or is described as belonging to the people, being close to the people, knowing the } \\
\text { people, speaking for the people, caring for the people, agreeing with the people or performing everyday actions. } \\
\text { The speaker claims to represent or embody the people. }\end{array}$ \\
\hline & Praising the people's virtues & $\begin{array}{l}\text { The people are attributed with positive traits such as morality, charisma, credibility, intelligence, competence, } \\
\text { consistency, etc. The people are exempt from being malevolent, criminal, lazy, stupid, extremist, racist, } \\
\text { undemocratic, etc. }\end{array}$ \\
\hline & Praising the people's achievements & $\begin{array}{l}\text { The people are described as being responsible for a positive development/situation, an achievement or benefit. } \\
\text { Achievements include important, successful, 'right' actions or other accomplishments. }\end{array}$ \\
\hline & $\begin{array}{l}\text { Describing the people as } \\
\text { homogenous }\end{array}$ & $\begin{array}{l}\text { The people are described as sharing a common understanding of the world, common feelings, desires, opinions, } \\
\text { or a common will. }\end{array}$ \\
\hline \multirow{3}{*}{ Anti-Elitism } & Discrediting the elite & $\begin{array}{l}\text { Negative personality traits, mistakes, and unlawful or immoral behavior of the elites are stressed. The elites are } \\
\text { portrayed as corrupt, malevolent, criminal, lazy, stupid, extremist, evil, undemocratic, etc. The elite are called } \\
\text { names and denied morality, charisma, credibility, intelligence, competence, consistency, etc. }\end{array}$ \\
\hline & Blaming the elite & $\begin{array}{l}\text { Elites are described as a threat/burden, or held responsible for negative developments/situations, specific failures, } \\
\text { or as having committed specific mistakes or crimes. }\end{array}$ \\
\hline & Detaching the elite from the people & $\begin{array}{l}\text { Elites are described as not belonging to the people, not being close to the people, not knowing the people, not } \\
\text { speaking for the people, not caring for the people, or not performing everyday actions. }\end{array}$ \\
\hline \multirow{2}{*}{ Sovereignty } & Demanding popular sovereignty & $\begin{array}{l}\text { The speaker argues for general institutional reforms to grant the people more power by introducing direct- } \\
\text { democratic elements or increasing political participation. The speaker argues in favor of granting more power to } \\
\text { the people within the context of a specific issue (e.g., election, immigration, security). }\end{array}$ \\
\hline & Denying elite sovereignty & $\begin{array}{l}\text { The speaker argues in favor of granting less power to elites within the context of a specific issue (e.g., election, } \\
\text { immigration, security). }\end{array}$ \\
\hline \multirow{3}{*}{ Exclusion } & Discrediting specific groups & $\begin{array}{l}\text { Specific social groups or population segments are discredited, denounced, or stigmatized. They are portrayed as } \\
\text { evil, criminal, lazy, stupid, immoral, dangerous, etc. }\end{array}$ \\
\hline & Blaming specific groups & $\begin{array}{l}\text { Specific social groups or population segments are held responsible for a negative, undesirable or harmful } \\
\text { development/situation. They are described as not being responsible for a positive development or situation. }\end{array}$ \\
\hline & Excluding specific groups & $\begin{array}{l}\text { Specific societal groups or population segments are characterized as 'others', juxtaposed to 'the people', } \\
\text { described as not belonging to the people, or not sharing their virtues. }\end{array}$ \\
\hline
\end{tabular}


Populism indices were calculated for the three speaker types, which were present if at least one of the twelve populist key messages was used in a story or comment by the respective speaker type.

Contextualization. In the event that there was a populist key message in a news story, we coded whether the author (i) disseminated the message neutrally, (ii) explicitly attenuated or criticized the message, (iii) provided a favorable context for the message that supported, reinforced, or legitimized it, or (iv) whether the author voiced populist key messages himself.

A team of ten intensively trained student coders had to pass several pretests as well as the final reliability test based on English-language material (31 online news articles and 30 reader comments, $n=61$ ) and reached acceptable levels of reliability. The average Brennan and Prediger's $K$ cross all populist key messages was .75. For the two speaker types (political speaker and media speaker), Brennan and Prediger's $K$ was .79, and the contextualization displayed a Brennan and Prediger's $K$ of .82 (see Table A in the online appendix).

\section{Analysis}

Depending on the specificities of the data and dependent variables, we employed different types of regression methods to answer the hypotheses. H1a and H1b were tested using negative binomial regression. This accounts for the right-skewed and overdispersed distribution of the count of comments per article, which served as the dependent variable. To test $\mathrm{H} 2 \mathrm{a}$ and $\mathrm{H} 2 \mathrm{~b}$ and answer RQ1, we conducted multilevel regression models containing fixed-effects components to account for the fact that reader comments are nested within the articles they respond to.

\section{Findings}

Overall, journalists from British, French, and Swiss online media used at least one populist 
key message in 65 percent $(n=214)$ of the news articles analyzed. In 61 percent of these cases $(n=131)$, the journalists conveyed a populist message that originally came from a politician; and in 37 percent $(n=79)$, the journalists made their own populist statement. In terms of dimensions, journalists most often included anti-elitist messages in their stories $(55 \%, n=181)$. Less often, they used or cited messages related to people-centrism $(22 \%, n=$ 72), exclusionism $(11 \%, n=35)$ or sovereignty $(5 \%, n=15)$. The articles received, on average, 272.48 comments $(M I N=1, M A X=3997, S D=601.67)$. Citizens voiced at least one populist key message in approximately a third $(34 \%, n=951)$ of all analyzed reader comments. Similar to the politicians and journalists, the citizens most often used anti-elitist key messages $(28 \%, n=786)$ and less often expressed key messages related to peoplecentrism $(3 \%, n=96)$, exclusion $(3 \%, n=94)$, or sovereignty $(1 \%, n=32) .{ }^{\mathrm{iii}}$

Table 3: The influence of populist communication in articles on the total number of comments

\begin{tabular}{|c|c|c|c|}
\hline & & \multicolumn{2}{|c|}{ Number of Comments } \\
\hline & & $I R R$ & $C I$ \\
\hline & (Intercept) & $61.46^{* * *}$ & {$[45.87,82.35]$} \\
\hline \multirow{2}{*}{ Country $^{\mathrm{a}}$} & United Kingdom & $8.76^{* * *}$ & {$[5.84,13.16]$} \\
\hline & France & $1.41^{*}$ & {$[1.01,1.99]$} \\
\hline \multirow{2}{*}{ Outlet $^{\mathrm{b}}$} & Mass-market & $0.50^{* * *}$ & {$[0.33,0.74]$} \\
\hline & Pure online & $0.24^{* * *}$ & {$[0.16,0.35]$} \\
\hline \multirow{2}{*}{ Article } & Populism by Political Speaker & $2.28^{* * * *}$ & {$[1.68,3.09]$} \\
\hline & Populism by Media Speaker & $1.80^{* * *}$ & {$[1.29,2.51]$} \\
\hline \multicolumn{2}{|l|}{$\mathrm{AIC}$} & \multicolumn{2}{|c|}{3863.81} \\
\hline \multicolumn{2}{|c|}{ Log likelihood } & \multicolumn{2}{|c|}{-1923.91} \\
\hline \multicolumn{2}{|c|}{ Omnibus-test } & \multicolumn{2}{|c|}{$236.82^{* * * *}(\mathrm{df}=6)$} \\
\hline \multicolumn{4}{|c|}{$\begin{array}{l}\text { Note: Negative binomial regression predicting the total number of comments in response to the articles }(\mathrm{N} \\
=332 \text { ). IRRs with confidence intervals in brackets. Values }<1 \text { indicate a negative effect; values }>1 \\
\text { indicate a positive effect. AIC = Akaike information criterion, IRR = incidence rate ratios, } \mathrm{CI}=\text { confidence } \\
\text { interval. }{ }^{\mathrm{a}} \text { Switzerland was set as baseline category. }{ }^{\mathrm{b}} \text { Up-market was set as baseline category. } \\
{ }^{*} p<.05,{ }^{* *} \quad p<.01, \quad p<.001\end{array}$} \\
\hline
\end{tabular}


Hypothesis 1 postulated a positive relationship between populist key messages in articles and the total number of comments they receive in return. A negative binomial regression controlling for differences between countries and outlet types (see Table 3), shows that, as expected, populist communication by political speakers as well as by media speakers in articles is positively and significantly associated with higher numbers of comments. For the interpretation of the results, we focus on the incidence rate ratios (IRR), which correspond to exponential b-coefficients. Values higher than 1 indicate a positive influence, and values below 1 indicate a negative influence on the number of reader comments an article receives. More precisely, when the independent variable is present (in the case of dummy variables), the expected count of reader comments has to be multiplied by the IRR (Trilling, Tolochko, \& Burscher, 2016). This suggests that articles in which journalists include populist statements by political actors trigger 2.28 times more reader comments, and articles in which journalists make their own populist statements drive up the number of reader comments by a factor of 1.80. This supports both H1a and H1b.

Observing the control variables, we see that news articles in Great Britain and France receive more reader comments overall than Swiss articles do and that readers of mass-market and pure online news websites comment less than readers of upmarket outlets.

To test hypotheses $\mathrm{H} 2 \mathrm{a}$ and $\mathrm{H} 2 \mathrm{~b}$ and answer RQ1, we conducted four multilevel models (see Table 4) with maximum-likelihood estimation (ML). The dependent variable in all four models is populist communication by citizens in reader comments, which indicates whether the commenter uses at least one populist key message. The units of analysis are reader comments, which are nested in the articles they respond to. Hence, the independent variables - source of the message (from the journalist himself or from a political source) and contextualization of the message (neutral transmission, negative attenuation or positive amplification by the journalist) - are both located at the second level, while the dependent 
variable is located at the first level. Additionally, we controlled for the length of a comment at the first level and for differences between types of outlets at the second level. ${ }^{\text {iv }}$

In a first step, we assessed whether it is useful to apply a multilevel model. If we compare the intercept-only model (Model 1) with the baseline model $\left(\chi^{2}(2)=19.81, p<\right.$ .001 ), we can conclude that the intercepts vary significantly across articles and significantly improved the model fit. In a second step, we added fixed-effects for the control variables (Model 2). As we can see in Table 4, the length of the reader comment has a significant impact on whether its author includes a populist message. It is relatively obvious that the longer a comment is, the more likely it is that it contains populist communication. The type of the outlet, however, does not have any significant influence on the amount of populism in reader comments. Thus, no differences can be found between upmarket, mass-market, or pure online outlets. A model comparison demonstrated that the model fit significantly increased for model $2\left(\chi^{2}(1)=128.87, p<.001\right)$.

Hypotheses $\mathrm{H} 2 \mathrm{a}$ and $\mathrm{H} 2 \mathrm{~b}$ predicted that populist communication by political speakers as well as by media speakers would increase the probability that citizens respond with populist key messages in their comments as well. To test these hypotheses, we added two fixed effects for populist communication by political speakers (dummy) and populist communication by media speakers (dummy) to the model. Again, a model comparison revealed that the model fit improves for model $3\left(\chi^{2}(1)=18.42, p<.001\right)$. We find clear support for both subhypotheses. Populist communication by political speakers $(\beta=0.086$, $t(326)=3.88, p<.001)$ and by media speakers $(\beta=0.051, t(326)=2.37, p<.05)$ significantly predict populist reactions in reader comments. On online news sites, citizens thus felt motivated to spread populist views and propositions if the underlying news articles also made populist statements. 
Table 4: Multi-level models predicting populist communication in reader comments

\begin{tabular}{|c|c|c|c|c|c|c|c|c|}
\hline & \multicolumn{8}{|c|}{ Populist Reader Comments } \\
\hline & \multicolumn{2}{|c|}{ Model 1} & \multicolumn{2}{|c|}{ Model 2} & \multicolumn{2}{|c|}{ Model 3} & \multicolumn{2}{|c|}{ Model 4} \\
\hline & $\beta$ & $(S E)$ & $\beta$ & $(S E)$ & $\beta$ & $(S E)$ & $\beta$ & $(S E)$ \\
\hline (Intercept) & -0.001 & $(0.022)$ & -0.001 & $(0.021)$ & -0.00 & $(0.021)$ & -0.00 & $(0.021)$ \\
\hline $\begin{array}{l}\text { Length of } \\
\text { comment }\end{array}$ & & & $0.216^{* * *}$ & $(0.019)$ & $0.219^{* * *}$ & $(0.019)$ & $0.217^{* * *}$ & $(0.020)$ \\
\hline $\begin{array}{l}\text { Mass-market } \\
\text { outlet }\end{array}$ & & & -0.017 & $(0.022)$ & -0.032 & $(0.023)$ & -0.034 & $(0.023)$ \\
\hline Pure online outlet & & & -0.042 & $(0.022)$ & -0.039 & $(0.022)$ & -0.041 & $(0.022)$ \\
\hline $\begin{array}{l}\text { Populism by } \\
\text { Political Speaker }\end{array}$ & & & & & $0.086^{* * *}$ & $(0.022)$ & $0.083^{* * *}$ & $(0.022)$ \\
\hline $\begin{array}{l}\text { Populism by } \\
\text { Media Speaker }\end{array}$ & & & & & $0.051^{*}$ & $(0.022)$ & & \\
\hline Attenuation & & & & & & & 0.017 & $(0.022)$ \\
\hline Amplification & & & & & & & 0.036 & $(0.021)$ \\
\hline AIC & 789 & .51 & 776 & 8.64 & 7754 & & 7758 & 61 \\
\hline $\mathrm{BIC}$ & 790 & .30 & 780 & 4.23 & 7801 & 68 & 7812 & 01 \\
\hline Log Likelihood & -384 & .75 & -387 & 8.32 & -3869 & & -3870 & 31 \\
\hline $\begin{array}{l}\text { Level } 1 \mathrm{~N} \\
\text { (Comments) }\end{array}$ & & 86 & 27 & 86 & 27 & & 27 & \\
\hline $\begin{array}{l}\text { Level } 2 \mathrm{~N} \\
\text { (Articles) }\end{array}$ & & 1 & 3. & 1 & 3. & & 33 & \\
\hline
\end{tabular}

Finally, RQ1 asked whether the contextualization of populist key messages by journalists might have an influence on the amount of populism in reader comments. To answer this question, we have added fixed effects to the model for whether journalists have either muted or strengthened (attenuated or amplified) populist statements by politicians. Since we regarded it also as amplification if the journalists themselves acted as the originators of populist key messages, model 4 does not include populism by media speakers as an independent variable. A model comparison showed that adding these variables does not improve the model fit $\left(\chi^{2}(1)=2.40, n . s.\right)$. Additionally, when we look at model 4, neither attenuation nor amplification have a significant effect on populism in reader comments, while populist communication by political speakers remains a significant factor $(\beta=0.083, t(325)=$ $3.74, p<.001)$. Thus, populist key messages by politicians seem to affect populism in reader 
comments regardless of whether these messages are attenuated, amplified, or transmitted neutrally by the media. For readers who operate with populist arguments, the interpretation and embedding by the journalist is largely irrelevant; such readers mainly focus on statements by politicians.

\section{Discussion and Conclusion}

This article set out to investigate how populism in the media affects the media users. Specifically, we analyzed the influence of populist statements by political and media actors in news articles on immigration on the number and content of reader comments during election periods in France, Switzerland, and the United Kingdom. Our findings suggest that populism in articles leads to more frequent and more populist reader comments. These effects may be explained by several causal mechanisms such as priming, framing, or emotional persuasion processes. Thus, populist messages in online news articles seem to hit a nerve with the readers by activating populist attitudes, in-group and out-group identifications, or eliciting emotions that prompt them to comment more and in a more populist manner.

Populism seems to generate more attention among readers and encourage citizens to engage in online discussions. As discussed above, this may be explained by populism's news value, its ability to mobilize citizens by activating in-group and out-group identifications, or emotional persuasion processes. On the one hand, this can be seen as desirable from a participatory viewpoint, if populist communication raises participation and possibly opinion diversity in the online public sphere. On the other hand, this may also help to propagate the populist key messages in the articles, which may be regarded as problematic from the perspective of liberal democracy, as we will elaborate below. In both cases, if populism generates a high user response, it may be beneficial from a commercial viewpoint for the media to cite or voice such messages in their content. 
Whether reader comments can be considered desirable, of course, depends on their content. In this regard, our results imply that populism in the news may incite more populist content by readers and, thus, foster a proliferation of populist ideas. In line with our theoretical expectations based on schema theory and similar argumentation by Müller et al. (2017), populist key messages in the news seem to have priming effects on citizens that activate a populism schema and prompt them to use such populist elements themselves in their responding reader comments.

Furthermore, it does not seem to matter whether journalists moderate populist messages by political actors or not. Neutrally transmitted populist key messages lead just as much to more populism in reader comments as attenuated or amplified populist statements do. This would imply that simply reporting on populist actors and their statements is sufficient to activate populist commenters. However, we only coded for explicit attenuation or amplification by journalists. Future research should include a more fine-grained measurement of moderation that includes any type of challenge or support for populist statements to conclusively answer this question, especially since other research suggests that populist statements are more often challenged by journalists, at least in print news (Wettstein et al., 2018).

If reader comments contribute to the dissemination of populist communication in the online public sphere, this can be regarded as problematic from the perspective of liberal democracy. While some scholars regard populism as an inherent feature of a democratic system (Canovan, 1999; Mény \& Surel, 2002), it is more often described as a threat, as populism undermines central aspects of liberal democracy (Abts \& Rummens, 2007; Taggart, 2000) and may negatively impact political communication (Waisbord, 2018). However, if a reader comment is populist, this does not necessarily mean that it is uncivil or impolite. In fact, our material showed that populist comments can indeed lead to arguments that may be 
considered as deliberative. Thus, citizens may also formulate legitimate criticism in a populist way. Additionally, as our data shows, exclusionist key messages, which are most closely linked to extreme right-wing or racist statements, are rather rare. Much more common is an anti-elitist rhetoric, mostly against the political establishment. First, this may have to do with the fact that media outlets may delete openly racist or discriminating comments. Second, during election campaigns, citizens may be specifically prone to voice their discontent with the political elite.

Some additional limitations need to be considered. First, although our study is comparative across three countries and different types of media outlets, the scope of our sample is limited. Thus, the found effects would need to be replicated in other countries, specifically with regard to non-Western or non-European countries. Additionally, with our focus on elections and the topic of immigration, we study populism under most-likely conditions. Populism in news articles as well as in reader comments may additionally be fueled by the polarized context of elections as well as by the controversial and populismaffine topic. Consequentially, the results can be generalized to other issues only with caution. Based on other recent studies (Ernst et al., 2018), we would expect the overall levels of populism in news articles to be lower for less populism-affine issues and therefore also the effects on reader comments to be weaker. Nevertheless, we believe that the high importance and prevalence of immigration in current political news renders our results specifically relevant for populist communication. Second, our sampling procedure leads to additional limitations. Since we only sample the first ten reader comments that directly respond to the articles, our findings may not apply to comment sections overall. However, existing research shows that not only the articles but also previous comments may influence if and how readers formulate subsequent comments (Zerback \& Fawzi, 2016; Ziegele et al., 2014; Ziegele, Weber, Quiring, \& Breiner, 2017). We therefore believe that the first ten reader comments are 
influenced less by the subsequent reader comments and more directly a response to the original article. On the other hand, primacy effect research lets us expect that the first ten reader comments receive the most attention from other users (e.g., Anderson, 1965).

Consequently, they may substantially influence subsequent reader comments and disproportionally steer the direction of the discussion in the comment section. Third, we do not know how the respective media outlets moderate their comment sections. Thus, the criteria for deleting comments are unclear and the comment function may be blocked entirely for certain articles. This could influence our results if populist communication was systematically related to being deleted by journalistic moderators. This is conceivable since populist communication is often associated with taboo-breaking and controversial language and the media outlets would probably delete reader comments that contain uncivil anti-elitist attacks or racist exclusionist statements. If this were the case, our results would rather underestimate the effects. Fourth, we did not code for other substantive characteristics of reader comments, such as incivility or deliberativeness. For future studies, it would be interesting to investigate how they relate to populist communication in reader comments. Finally, relying solely on content analysis of digital trace data has certain limits. For one thing, we cannot control for citizens' attitudes, sociodemographic characteristics or political opinions. Only a small share of online news readers actually use the comment function; hence, reader comments are not representative of public opinion (Springer et al., 2015; Walter et al., 2016). Thus, our findings may only apply to a specific group of people who are particularly prone to comment on news articles as one of the first commenters. Nevertheless, we believe that these comments are relevant as they may also influence attitudes, opinions, or perceptions of public opinion of inactive observers that only read comment sections without commenting themselves (Lee, 2012; Lee \& Jang, 2010; Zerback \& Fawzi, 2016). Moreover, although our findings confirm our theoretical expectations that populist communication has 
priming effects, we cannot effectively determine which underlying cognitive or affective processes explain these effects best. This is a disadvantage in comparison to experimental settings in exchange for the higher validity of digital trace data. Future research can determine which theoretical model fits best.

Overall, our study demonstrates that (1) populist key messages resonate with citizens and are disseminated by them (populism resonates); (2) populist key messages lead to more populist key messages (populism multiplies); and (3) we find that, at least in our case, journalistic contextualization does not matter significantly. With the continuing rise of populist political actors in several countries, such as France, Switzerland, and the United Kingdom, specifically on the right side of the political spectrum, the media is repeatedly confronted with the question of how to cover such populist actors and issues. Although other recent studies suggest that the media often challenge populist actors and their statements (Wettstein et al., 2018), our results imply that even the attenuation of populist messages by media speakers does not lead to a reduced number of populist reader comments. While a high participation in the online public sphere is desirable, high levels of populism may have negative consequences for political communication in liberal democracies. Therefore, we need more research on how citizens react and contribute to online populist communication.

\section{References}

Aalberg, T., Esser, F., Reinemann, C., Strömbäck, J., \& de Vreese, C. (Eds.). (2017). Populist Political Communication in Europe. New York: Routledge.

Abts, K., \& Rummens, S. (2007). Populism versus democracy. Political Studies, 55(2), 405424.

Albertazzi, D., \& McDonnell, D. (2008). Introduction: A new spectre for Western Europe. In D. Albertazzi \& D. McDonnell (Eds.), Twenty-first century populism: the spectre of Western European democracy (pp. 1-11). Basingstoke: Palgrave Macmillan.

Anderson, C. W. (2011). Between creative and quantified audiences: Web metrics and changing patterns of newswork in local US newsrooms. Journalism, 12(5), 550-566.

Armitage, C. J., \& Conner, M. (2001). Efficacy of the Theory of Planned Behaviour: A metaanalytic review. British Journal of Social Psychology, 40(4), 471-499. 
Aslanidis, P. (2015). Is Populism an Ideology?: A Refutation and a New Perspective. Political Studies. (Published online before print), 1-17.

Bartlett, F. C., \& Burt, C. (1933). Remembering: A Study in Experimental and Social Psychology. British Journal of Educational Psychology, 3(2), 187-192.

Bene, M. (2017). Go viral on the Facebook!: Interactions between candidates and followers on Facebook during the Hungarian general election campaign of 2014. Information, Communication \& Society, 20(4), 513-529.

Blassnig, S., Ernst, N., Büchel, F., \& Engesser, S. (2018). Populist communication in talk shows and social media: A comparative content analysis in four countries. SCM Studies in Communication and Media, 7(3), 338-363.

Blassnig, S., Ernst, N., Büchel, F., Engesser, S., \& Esser, F. (2019). Populism in Online Election Coverage. Journalism Studies, 20(8), 1110-1129.

Blassnig, S., Ernst, N., Engesser, S., \& Esser, F. (forthcoming). Populism and Social Media Popularity: How Populist Communication Benefits Political Leaders on Facebook and Twitter. In D. Taras \& R. Davis (Eds.), Social Media and the New Politics of Political Leadership: Case studies in Political Communication. Routledge.

Blumler, J. G., \& Kavanagh, D. (1999). The Third Age of Political Communication: Influences and Features. Political Communication, 16(3), 209-230.

Bobba, G. (2018). Social media populism: Features and 'likeability' of Lega Nord communication on Facebook. European Political Science, 1-13.

Bos, L., van der Brug, W., \& de Vreese, C. (2011). How the Media Shape Perceptions of Right-Wing Populist Leaders. Political Communication, 28(2), 182-206.

Bos, L., van der Brug, W., \& de Vreese, C. (2013). An experimental test of the impact of style and rhetoric on the perception of right-wing populist and mainstream party leaders. Acta Politica, 48(2), 192-208.

Brewer, W. F., \& Nakamura, G. V. (1984). The nature and functions of schemas: (Center for the Study of Reading Technical Report No. 325). Champaign, IL: University of Illinois at Urbana-Champaign.

Canovan, M. (1999). Trust the people! Populism and the two faces of democracy. Political Studies, 47(1), 2-16.

Coe, K., Kenski, K., \& Rains, S. A. (2014). Online and Uncivil?: Patterns and Determinants of Incivility in Newspaper Website Comments. Journal of Communication, 64(4), 658679.

Cranmer, M. (2011). Populist Communication and Publicity: An Empirical Study of Contextual Differences in Switzerland. Swiss Political Science Review, 17(3), 286-307.

Dahlberg, L. (2011). Re-constructing digital democracy: An outline of four 'positions'. New Media \& Society, 13(6), 855-872.

De Vreese, C., Esser, F., Aalberg, T., Reinemann, C., \& Stanyer, J. (2018). Populism as an Expression of Political Communication Content and Style: A New Perspective. The International Journal of Press/Politics, 23(4), 423-438.

Diamantopoulos, A., Riefler, P., \& Roth, K. P. (2008). Advancing formative measurement models. Journal of Business Research, 61(12), 1203-1218.

Engesser, S., Fawzi, N., \& Larsson, A. O. (2017). Populist online communication: Introduction to the special issue. Information, Communication \& Society, 20(9), 12791292. 
Ernst, N., Blassnig, S., Engesser, S., Büchel, F., \& Esser, F. (2019). Populists Prefer Social Media Over Talk Shows: An Analysis of Populist Messages and Stylistic Elements Across Six Countries. Social Media + Society, 5(1), 1-14.

Ernst, N., Engesser, S., Büchel, F., Blassnig, S., \& Esser, F. (2017). Extreme parties and populism: An analysis of Facebook and Twitter across six countries. Information, Communication \& Society, 20(9), 1347-1364.

Ernst, N., Esser, F., Blassnig, S., \& Engesser, S. (2018). Favorable Opportunity Structures for Populist Communication: Comparing Different Types of Politicians and Issues in Social Media, Television and the Press. The International Journal of Press/Politics, 24(2), 165188.

Esser, F., Stępińska, A., \& Hopmann, David. (2017). Populism and the Media: Cross-National Findings and Perspectives. In T. Aalberg, F. Esser, C. Reinemann, J. Strömbäck, \& C. de Vreese (Eds.), Populist Political Communication in Europe (pp. 365-380). New York: Routledge.

Esser, F., Stępińska, A., Pekacek, O., Seddone, A., Papathanassopoulos, S., Peicheva, D., . . . Engesser, S. (2019). Event-, Politics-, and Audience-Driven News: A Two-Year Comparison of Populism in European Media Coverage. In C. Reinemann, J. Stanyer, T. Aalberg, F. Esser, \& C. H. de Vreese (Eds.), Communicating Populism: Comparing actor perceptions, media coverage, and. [S.1.]: Routledge.

Esser, F., \& Strömbäck, J. (2012). Comparing News on National Elections. In F. Esser \& T. Hanitzsch (Eds.), International Communication Association (ICA) handbook series. Handbook of comparative communication research (pp. 308-326). New York, N.Y: Routledge.

Esser, F., \& Vliegenthart, R. (2017). Comparative Research Methods. In J. Matthes (Ed.), The International Encyclopedia of Communication Research Methods (pp. 1-22). John Wiley \& Sons, Inc.

Fletcher, R., \& Nielsen, R. K. (2017). Are News Audiences Increasingly Fragmented?: A Cross-National Comparative Analysis of Cross-Platform News Audience Fragmentation and Duplication. Journal of Communication, 67(4), 476-498.

Freelon, D. (2015). Discourse architecture, ideology, and democratic norms in online political discussion. New Media \& Society, 17(5), 772-791.

Gervais, B. T. (2014). Following the News?: Reception of Uncivil Partisan Media and the Use of Incivility in Political Expression. Political Communication, 31(4), 564-583.

Hameleers, M., Bos, L., Fawzi, N., Reinemann, C., Andreadis, I., Corbu, N., . . . WeissYaniv, N. (2018). Start Spreading the News: A Comparative Experiment on the Effects of Populist Communication on Political Engagement in Sixteen European Countries. The International Journal of Press/Politics, 23(4), 517-538.

Hameleers, M., Bos, L., \& Vreese, C. H. de. (2017). “They Did It”: The Effects of Emotionalized Blame Attribution in Populist Communication. Communication Research, 44(6), 870-900.

Hameleers, M., Bos, L., \& Vreese, C. H. de. (2018). Selective Exposure to Populist Communication: How Attitudinal Congruence Drives the Effects of Populist Attributions of Blame. Journal of Communication, 68(1), 51-74.

Hameleers, M., \& Schmuck, Desirée. (2017). It's us against them: A comparative experiment on the effects of populist messages communicated via social media. Information, Communication \& Society, 1-20. 
Hawkins, K. A., Carlin, R. E., Littvay, L., \& Rovira Kaltwasser, C. (Eds.). (2018). Extremism and democracy. The ideational approach to populism: Concept, theory, and analysis: Routledge.

Hawkins, K. A., \& Kaltwasser, C. R. (2018). Introduction: The Ideational Approach. In K. A. Hawkins, R. E. Carlin, L. Littvay, \& C. Rovira Kaltwasser (Eds.), Extremism and democracy. The ideational approach to populism: Concept, theory, and analysis (pp. 124). Routledge.

Heiss, R., Schmuck, Desiree, \& Matthes, Jörg. (2018). What drives interaction in political actors' Facebook posts?: Profile and content predictors of user engagement and political actors' reactions. Information, Communication \& Society, 1-17.

Howison, J., Wiggins, A., \& Crowston, K. (2011). Validity Issues in the Use of Social Network Analysis with Digital Trace Data. Journal of the Association for Information Systems, 12(12), 767-797.

Iran-Nejad, A. (1984). The schema: A structural or a functional pattern: (Center for the Study of Reading Technical Report No. 159). Champaign, IL: University of Illinois at UrbanaChampaign.

Jagers, J., \& Walgrave, S. (2007). Populism as political communication style: An empirical study of political parties' discourse in Belgium. European Journal of Political Research, 46(3), 319-345.

Jamieson, K. H., \& Cappella, J. N. (2010). Echo chamber: Rush Limbaugh and the conservative media establishment. Oxford: Oxford University Press.

Krämer, B. (2014). Media populism: a conceptual clarification and some theses on its effects. Communication Theory, 24(1), 42-60.

Krämer, B. (2017). Populist online practices: The function of the Internet in right-wing populism. Information, Communication \& Society, 20(9), 1293-1309.

Lee, E.-J. (2012). That's Not the Way It Is: How User-Generated Comments on the News Affect Perceived Media Bias. Journal of Computer-Mediated Communication, 18(1), 3245.

Lee, E.-J., \& Jang, Y. J. (2010). What Do Others' Reactions to News on Internet Portal Sites Tell Us?: Effects of Presentation Format and Readers' Need for Cognition on Reality Perception. Communication Research, 37(6), 825-846.

Lewis, S. C., Holton, A. E., \& Coddington, M. (2013). Reciprocal Journalism. Journalism Practice, 8(2), 229-241.

Matthes, Jörg, \& Schmuck, Desirée. (2017). The Effects of Anti-Immigrant Right-Wing Populist Ads on Implicit and Explicit Attitudes: A Moderated Mediation Model. Communication Research, 44(4), 556-581.

Mazzoleni, G. (2008). Populism and the media. In D. Albertazzi \& D. McDonnell (Eds.), Twenty-first century populism: the spectre of Western European democracy (pp. 49-64). Basingstoke: Palgrave Macmillan.

Mény, Y., \& Surel, Y. (2002). The Constitutitive Ambiguity of Populism. In Y. Mény \& Y. Surel (Eds.), Democracies and the populist challenge (pp. 1-21). Basingstoke: Palgrave.

Moffitt, B. (2016). The global rise of populism: Performance, political style, and representation. Stanford, California: Stanford University Press.

Mudde, C. (2004). The populist Zeitgeist. Government and Opposition, 39(4), 542-563.

Müller, P., Schemer, C., Wettstein, M., Schulz, A., Wirz, Dominique S., Engesser, S., \& Wirth, W. (2017). The Polarizing Impact of News Coverage on Populist Attitudes in the 
Public: Evidence From a Panel Study in Four European Democracies. Journal of Communication, 67(6), 968-992.

Perugini, M., \& Bagozzi, R. P. (2001). The role of desires and anticipated emotions in goaldirected behaviours: Broadening and deepening the theory of planned behaviour. British Journal of Social Psychology, 40(1), 79-98.

Plasser, F., \& Ulram, P. A. (2003). Striking a responsive chord: Mass media and right-wing populism in Austria. In G. Mazzoleni (Ed.), Praeger series in political communication. The media and neo-populism: a contemporary comparative analysis (pp. 21-43). Westport, Conn: Praeger.

Porten-Cheé, P., Haßler, J., Jost, P., Eilders, C., \& Maurer, M. (2018). Popularity cues in online media: Theoretical and methodological perspectives. SCM Studies in Communication and Media, 7(2), 80-102.

Roskos-Ewoldsen, D., Roskos-Ewoldsen, B., \& Carpentier, F. R. D. (2002). Media priming: A synthesis. In J. Bryant \& D. Zillmann (Eds.), LEA's communication series. Media effects: Advances in theory and research (2nd ed., pp. 97-120). Mahwah, NJ: Lawrence Elbaum.

Ruiz, C., Domingo, D., Micó, J. L., Díaz-Noci, J., Meso, K., \& Masip, P. (2011). Public Sphere 2.0?: The Democratic Qualities of Citizen Debates in Online Newspapers. The International Journal of Press/Politics, 16(4), 463-487.

Salgado, S., Stanyer, J., Hajzer, G., Hopmann, David N., Kalsnes, B., Legnante, G., . . Sanders, Karen B. (2019). Politicians' Perceptions of Populism and the Media: A CrossNational Study Based on Semi-Structured Interviews. In C. Reinemann, J. Stanyer, T. Aalberg, F. Esser, \& C. H. de Vreese (Eds.), Communicating Populism: Comparing actor perceptions, media coverage, and. [S.1.]: Routledge.

Schulz, A., Wirth, W., \& Müller, P. (2018). We Are the People and You Are Fake News: A Social Identity Approach to Populist Citizens' False Consensus and Hostile Media Perceptions. Communication Research, 1-26.

Sheets, P., Bos, L., \& Boomgaarden, Hajo G. (2016). Media Cues and Citizen Support for Right-Wing Populist Parties. International Journal of Public Opinion Research, 28(3), 307-330.

Simon, B., \& Klandermans, B. (2001). Politicized collective identity: A social psychological analysis. American Psychologist, 56(4), 319-331.

Springer, N., Engelmann, I., \& Pfaffinger, C. (2015). User comments: Motives and inhibitors to write and read. Information, Communication \& Society, 18(7), 798-815.

Stanyer, J., Salgado, S., Bobba, G., Hajzer, G., Hopmann, David N., Vochocova, L., . . . Hubé, N. (2019). Journalists' Perceptions of Populism and the Media: A Cross-National Study Based on Semi-Structured Interviews. In C. Reinemann, J. Stanyer, T. Aalberg, F. Esser, \& C. H. de Vreese (Eds.), Communicating Populism: Comparing actor perceptions, media coverage, and. [S.1.]: Routledge.

Stanyer, J., Salgado, S., \& Strömbäck, J. (2017). Populist Actors as Communicators or Political Actors as Populist Communicators: Cross-National Findings and Perspectives. In T. Aalberg, F. Esser, C. Reinemann, J. Strömbäck, \& C. de Vreese (Eds.), Populist Political Communication in Europe (pp. 353-364). New York: Routledge.

Stroud, N. J., Scacco, J. M., Muddiman, A., \& Curry, A. L. (2015). Changing Deliberative Norms on News Organizations' Facebook Sites. Journal of Computer-Mediated Communication, 20(2), 188-203.

Sunstein, C. R. (2002). Republic.com. Princeton, NJ: Princeton Univ. Press. 
Taggart, P. (2000). Populism. Concepts in the social sciences. Buckingham: Open University Press.

Taggart, P. (2017). Populism in Western Europe. In C. Rovira Kaltwasser, P. A. Taggart, P. Ochoa Espejo, \& P. Ostiguy (Eds.), The Oxford handbook of populism (pp. 248-266).

Oxford, New York, NY: Oxford University Press.

Tajfel, H., \& Turner, J. C. (2004). The Social Identity Theory of Intergroup Behavior. In J. T. Jost \& J. Sidanius (Eds.), Political psychology: Key readings (pp. 276-293). New York: Psychology Press.

Tenenboim, O., \& Cohen, A. A. (2014). What prompts users to click and comment: A longitudinal study of online news. Journalism: Theory, Practice \& Criticism, 16(2), 198217.

Toepfl, F., \& Piwoni, E. (2015). Public Spheres in Interaction: Comment Sections of News Websites as Counterpublic Spaces. Journal of Communication, 65(3), 465-488.

Toepfl, F., \& Piwoni, E. (2017). Targeting dominant publics: How counterpublic commenters align their efforts with mainstream news. New Media \& Society, 9, 2011-2027.

Trilling, D., Tolochko, P., \& Burscher, B. (2016). From Newsworthiness to Shareworthiness: How to Predict News Sharing Based on Article Characteristics. Journalism \& Mass Communication Quarterly, 94(1), 38-60.

Van Aelst, P., Strömbäck, J., Aalberg, T., Esser, F., de Vreese, C., Matthes, Jörg, . . Stanyer, J. (2017). Political communication in a high-choice media environment: a challenge for democracy? Annals of the International Communication Association, 41(1), 3-27.

Van Zomeren, M., Postmes, T., \& Spears, R. (2008). Toward an integrative social identity model of collective action: a quantitative research synthesis of three socio-psychological perspectives. Psychological Bulletin, 134(4), 504-535.

Vujnovic, M. (2011). Participatory Journalism in the Marketplace: Economic Motivations behind the Practices. In J. B. Singer, A. Hermida, D. Domingo, A. Heinonen, S. Paukussen, T. Quandt, ... M. Vujnovic (Eds.), Participatory Journalism in Online Newspapers: Guarding the Internet's Open Gates (pp. 139-154). Boston: WileyBlackwell.

Waisbord, S. (2018). Why Populism is Troubling for Democratic Communication. Communication, Culture and Critique, 11(1), 21-34.

Walter, S., Brüggemann, M., \& Engesser, S. (2016). Echo Chambers of Denial: Explaining User Comments on Climate Change. Environmental Communication, 12(2), 204-217.

Weber, P. (2014). Discussions in the comments section: Factors influencing participation and interactivity in online newspapers' reader comments. New Media \& Society, 16(6), 941957.

Webster, J. G., \& Ksiazek, T. B. (2012). The Dynamics of Audience Fragmentation: Public Attention in an Age of Digital Media. Journal of Communication, 62(1), 39-56.

Wettstein, M., Esser, F., Schulz, A., Wirz, Dominique Stefanie, \& Wirth, W. (2018). News Media as Gatekeepers, Critics, and Initiators of Populist Communication: How Journalists in Ten Countries Deal with the Populist Challenge. The International Journal of Press/Politics, 23(4), 476-495.

Wirth, W., Esser, F., Engesser, S., Wirz, Dominique, Schulz, A., Ernst, N., . . Schemer, C. (2016). The appeal of populist ideas, strategies and styles: A theoretical model and research design for analyzing populist political communication. Zürich: NCCR Democracy, Working Paper No. 88, pp. 1-60. Retrieved from http://www.nccrdemocracy.uzh.ch/publications/workingpaper/wp88 
Wirz, Dominique S. (2018a). Does consistency matter? Perception and persuasiveness of value appeals in populist communication. SCM Studies in Communication and Media, 7(1), 59-88.

Wirz, Dominique S. (2018b). Persuasion Through Emotion? An Experimental Test of the Emotion-Eliciting Nature of Populist Communication. International Journal of Communication, 12, 1114-1138.

Wirz, Dominique S., Wettstein, M., Schulz, A., Müller, P., Schemer, C., Ernst, N., . . Wirth, W. (2018). The Effects of Right-Wing Populist Communication on Emotions and Cognitions toward Immigrants. The International Journal of Press/Politics, 23(4), 496516.

Zerback, T., \& Fawzi, N. (2016). Can online exemplars trigger a spiral of silence?: Examining the effects of exemplar opinions on perceptions of public opinion and speaking out. New Media \& Society, 19(7), 1034-1051.

Ziegele, M., Breiner, T., \& Quiring, O. (2014). What Creates Interactivity in Online News Discussions?: An Exploratory Analysis of Discussion Factors in User Comments on News Items. Journal of Communication, 64(6), 1111-1138.

Ziegele, M., Quiring, O., Esau, K., \& Friess, D. (2018). Linking News Value Theory With Online Deliberation: How News Factors and Illustration Factors in News Articles Affect the Deliberative Quality of User Discussions in SNS' Comment Sections. Communication Research, 12(2), 1-31.

Ziegele, M., Weber, M., Quiring, O., \& Breiner, T. (2017). The dynamics of online news discussions: Effects of news articles and reader comments on users' involvement, willingness to participate, and the civility of their contributions. Information, Communication \& Society, 7, 1-17.

\section{${ }^{1}$ Notes}

${ }^{1}$ The search strings for the three different countries were as follows:

$\mathrm{CH}$ : migration OR immigration OR zuwanderung OR flüchtling $\mathrm{OR}$ ausländer $\mathrm{OR}$ asyl $\mathrm{OR}$ einbürgerung OR ausschaffung "SVP" OR "SP" OR "Lega" OR "FDP"

UK: migration OR immigration OR refugee OR foreigner OR asylum OR naturalisation OR deportation Labour OR "Scottish National Party" OR SNP OR "Liberal Democrats" OR "Lib Dems"

FR: migration OR immigration OR réfugié OR étranger OR asile OR naturalisation OR expuls OR reconduite "Front National" OR "FN" OR "Parti socialiste" OR "PS" OR "Corsica Libera" OR "Parti libéral démocrate" OR "PLD"

${ }^{2}$ For those news outlets where it was not possible to change the order of the reader comments (Le Figaro, Le Monde, Le Parisien, Rue89, Blick, SRF, Watson), the ten newest reader comments were selected for the sample.

iii An overview of descriptive statistics for all variables can be found in Tables C and D in the online appendix.

${ }^{\text {iv }}$ As additional robustness checks, we ran the multi-level models with the three countries as well as with the 16 news outlets as additional random effects on the third level of the models. Either way, we could replicate the same results for all four models. However, since the inclusion of a third level did not improve model fit, we preferred the presented models with two levels. 